\title{
Parasitological and Biochemical Studies on Chalcides ocellatus Inhabiting Damietta Region
}

\author{
A.A. Khidr*, G.A. Abd-Allah, A.E. Said, A.M. Ghoneim, Y.M. Fouad \\ Zoology Department, Faculty of Science, Damietta University, Egypt
}

Received: 05 May 2013 / Accepted: 16 June 2013

*Corresponding author (email: nectar rose87@ yahoo.com)

\begin{abstract}
At least 400 species of reptiles occur in Egypt, however little attention has been given to their parasite community. In this paper, we tried to address the intestinal parasite funa in the lizard chalcides ocellatus and the effect of parasitic infection on its blood biochemical parameters. Lizards were collected from both costal and agricultural regions in Damietta region during three different periods. Our extensive search for parasites infecting this lizard showed that parapharyngodon bulbous is a dominant endoparasite of this lizard. In addition to determining the prevalence of this nematode, the changes in the concentration of different blood parameters and the correlation between parasite prevalence and these parameters were investigated. Data showed that there is no difference in the prevalence of parasites between costal and agricultural regions, but the prevalence of parasites differed from one season to another. With respect to the blood biochemical parameters, our results showed that the concentration of serum triglycerides, cholesterol, calcium, sodium and glucose were higher in lizards collected from costal region, while serum HDLcholesterol, total protein and albumin concentrations were higher in lizards collected from agricultural region. A positive and negative relation between the parasite prevalence and a number of biochemical parameters was also recorded.
\end{abstract}

Keywords: Chalcides, parasite, Parapharyngodon, biochemical parameters, parasite prevalence, seasonal variation

\section{Introduction}

The community structure of vertebrate parasites has attracted considerable interest in the last decade and resulted in the development of conceptual framework for the hierarchical structure of parasite communities [1]. This has enabled the formulation of hypotheses about the key processes that regulate the composition and structure of parasite component communities [2]. There are more than 400 species of reptiles that occur in Egypt [3]. Unfortunately, little attention has been given to their helminth community and few records exist in the literatures .Those that do exist are mostly of a taxonomic nature. One of the most abundant and widespread reptiles in Africa and Egypt is the lizard C. ocellatus where its distribution is primarily attributed to its tolerance to diverse environments that range from the steppe through agricultural fields to woodland habitats [3].

In this work, we aimed to study the parasite infracommunity structure of the lizard $C$. ocellatus found at Damietta region and the possible effects of seasons on the prevelance of parasites, as well as the influence of prevelance 
of these parasites on the blood biochemical physiological parameters of the lizard.

\section{Materials and methods}

\section{Collection of lizards}

During this study, a total of 100 lizards (male \& female) of different sizes belonging to genus Chalcides were collected during the period from May 2010 to July 2012 from both costal and agricultural regions in Damietta region (New Damietta). Lizards were kept alive in cages with sand and some grasses at room temperature until complete investigation.

\section{Parasitological \& biochemical studies}

Blood samples were collected from different lizards by cutting of the tail tips, then the blood of each animal was divided into two groups, the first was used to make thin blood smears for detection of the blood parasites. The second group was collected in centrifuge tubes containing heparin then the samples were centrifuged at $5000 \mathrm{rpm}$ for 5 minutes and sera of all samples were separated and transferred into clean eppendorf tubes for measuring biochemical parameters. Glucose, triglycerides, cholesterol, HDL-cholesterol, LDL-cholesterol, total protein, albumin, calcium and sodium were estimated by aid of commercial kits obtained from Biomed Diagnostics Company, Egypt according to the manufacturer's instructions.

\section{Statistical analysis}

The statistical package for the social sciences version 8 (SPSS) was used for analysis of all data. One way and two way Anova tests were used

\section{Results}

Our extensive search for parasites infecting the lizard $C$. ocellatus resulted in the dominance of an intestinal nematode parasite that was identified as P. bulbous.

\section{Prevalence of parasites}

Forty-four out of sixty five lizards (67.7\%) were found infected by $P$. bulbous. The prevalence of nematode in lizards collected from costal region was $65.52 \%$ ( $\mathrm{n}=19$ infected) while in the lizards collected from agricultural region the prevalence was $71.4 \%$ ( $\mathrm{n}=25$ infected). Concerning seasonal variation, our results showed that the prevalence of $P$. bulbous in both costal and agricultural regions was high during summer which reached $83.33 \%, 90.9 \%$ respectively (Table 1 ). The statistical analysis showed that parasite prevalence differ significantly $(\mathrm{p}=0.05)$ over the three periods but there is no differences in the parasite prevalence between the costal and agricultural regions.

Table 1. Prevalence of parasites in costal and agricultural regions of Damietta region at different periods

\begin{tabular}{|c|c|c|}
\hline & $\begin{array}{l}\text { No. of } \\
\text { infected lizards }\end{array}$ & prevalence \\
\hline Costal & 19 & $65.52 \%$ \\
\hline Agricultural & 25 & $71.43 \%$ \\
\hline \multicolumn{3}{|l|}{ Costal } \\
\hline Period $1 *$ & 12 & $70.59 \%$ \\
\hline Period 2 & 2 & $33.33 \%$ \\
\hline Period 3 & 5 & $83.33 \%$ \\
\hline \multicolumn{3}{|l|}{ Agricultural } \\
\hline Period 1 & 8 & $61.54 \%$ \\
\hline Period 2 & 7 & $58.33 \%$ \\
\hline Period 3 & 10 & $90.9 \%$ \\
\hline
\end{tabular}

* Period 1, May-July 2010; Period 2, JanuaryFebrauary2011; period 3, May-July 2011

\section{Biochemical parameters}

\section{Glucose}

Although the high concentration in Costal region, serum glucose in both costal and agricultural regions did not show a significant difference within the period or regardless of the period as tested by one-way ANOVA (Fig. 1).

As seen in Fig. 2, the level of serum triglycerides reached a maximum concentration in period 3.It was significantly different $(\mathrm{p}=0.05)$, $(\mathrm{p}=0.01)$ between costal and agricultural regions, respectively over the three periods as tested by one-way ANOVA. However, there was no significant difference as tested by two-way in serum triglycerides concentrations between both costal and agricultural regions regardless of the period. 


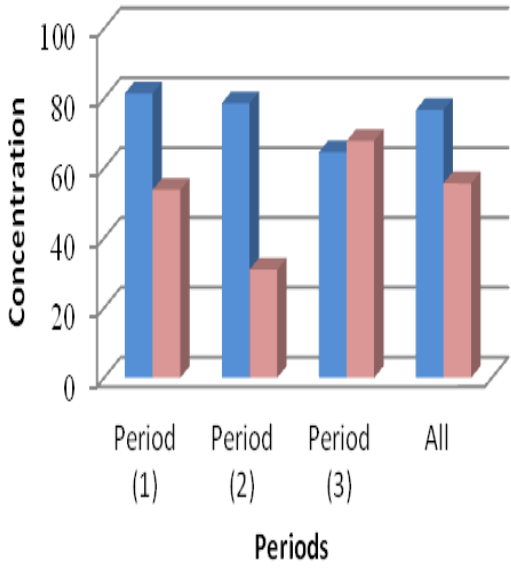

Fig. 1 Diagram showing the concentration of glucose in both costal and agricultural regions at three periods. There is no significant difference as tested by one-way ANOVA. "All" refers to the difference in the concentration of glucose in the 3 periods collectively between costal and agricultural regions Triglycerides

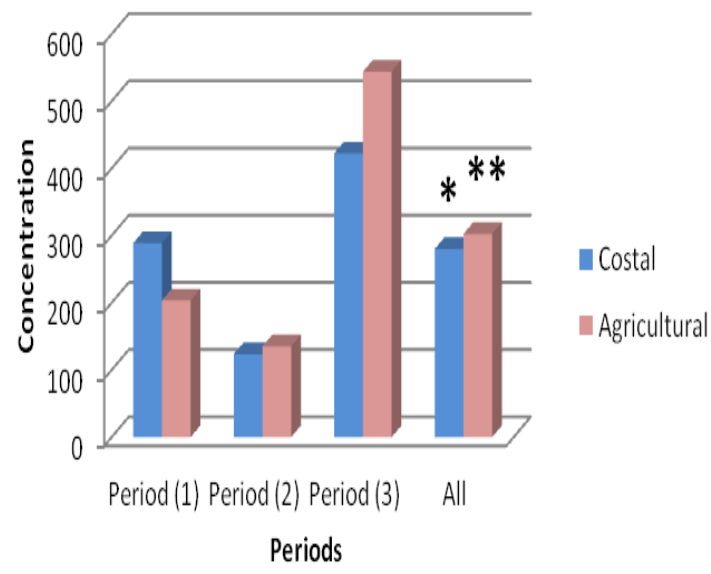

Fig. 2 Diagram showing the concentration of triglycerides in both costal and agricultural regions at three periods. $(*)$, refers to a 0.05 significance level. $(* *)$ and refers to a 0.01 significance level as tested by one-way ANOVA. "All" refers to the difference in the concentration of triglycerides in the 3 periods collectively between costal and agricultural regions.

\section{Cholesterol}

A little increase in cholesterol concentration was recorded in the Costal region in period 1 and 2, however there was no significant difference as tested by one-way ANOVA in serum cholesterol concentrations between both costal and agricultural regions at the three different periods (Fig. 3). Regardless of the period, there was no significant difference between costal and agricultural regions.

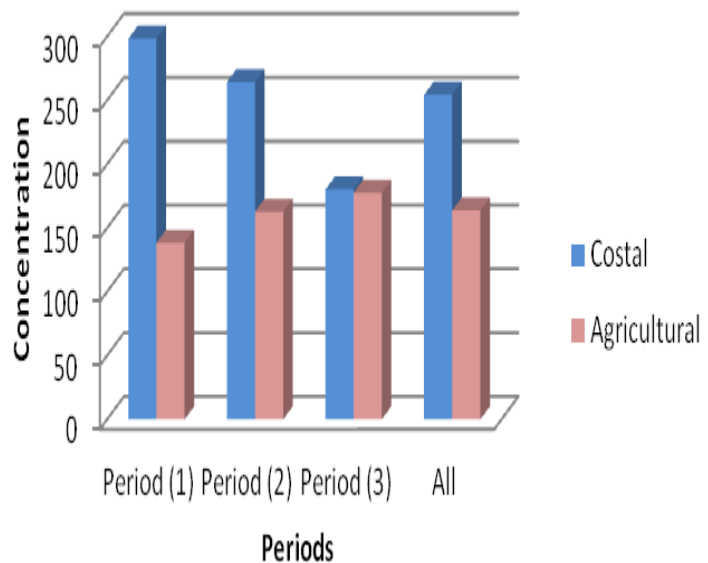

Fig. 3 Diagram showing the concentration of cholesterol in both costal and agricultural regions at three periods. There is no significant difference as tested by one-way ANOVA. "All" refers to the difference in the concentration of cholesterol in the 3 periods collectively between costal and agricultural regions.

\section{HDL-cholesterol}

There was no significant difference as tested by one-way ANOVA regarding the concentration of HDL-cholesterol between the different periods. As seen in Fig. 4, the level of serum HDLcholesterol was significantly higher $(p=0.01)$ in agricultural region when compared to costal region regardless of the period as tested by twoway ANOVA.

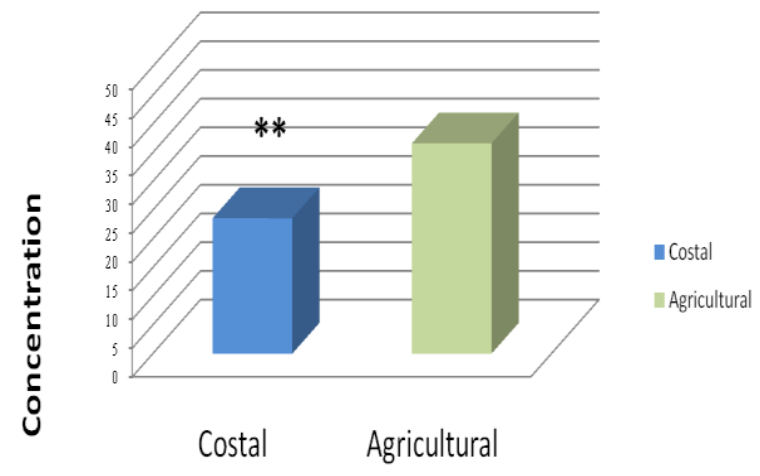

HDL-cholesterol

Fig. 4 Diagram showing the concentration of HDLcholesterol in both costal and agricultural regions regardless of the period. (**), refers to a 0.01 significance level as tested by two-way ANOVA. 


\section{LDL-cholesterol}

Serum LDL-cholesterol did not show a significant difference between the three periods as tested by one-way ANOVA. As seen in Fig. 5, the level of serum LDL-cholesterol was no significance difference as tested by two-way ANOVA between both costal and agricultural regions regardless of the period.

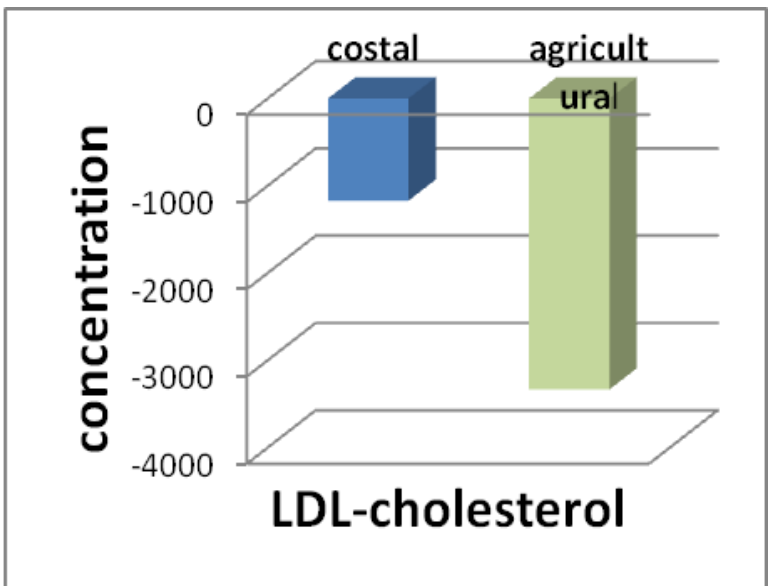

Fig. 5 Diagram showing the concentration of LDLcholesterol in both costal and agricultural. There is no significant difference as tested by two-way ANOVA.

\section{Total protein}

Serum total protein of lizards was higher a little in the agricultural region at the three periods (Fig. $6)$. The overall level of serum protein was significantly different $(\mathrm{p}=0.05)$ in agricultural region as tested by one-way ANOVA.

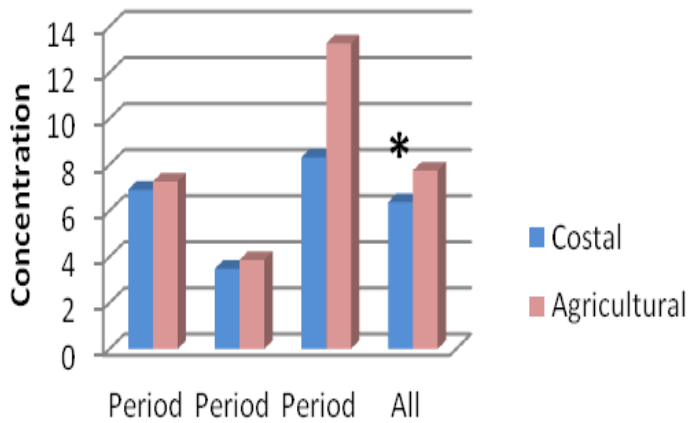

(1) (2) (3)

Periods

Fig. 6 Diagram showing the concentration of total protein in both costal and agricultural regions at three periods. (*), refers to 0.05 significance level as tested by one-way ANOVA. "All" refers to the difference in the concentration of total protein in the 3 periods collectively between costal and agricultural regions.

\section{Albumin}

The level of serum albumin was significantly higher $(\mathrm{p}=0.01)$ in agricultural region when compared to its concentration in Costal region, over the three periods as tested by one-way ANOVA (Fig. 7). Also, the concentrations of serum albumin was significantly different $(p=0.05)$ with respect to the period as tested by one-way ANOVA.

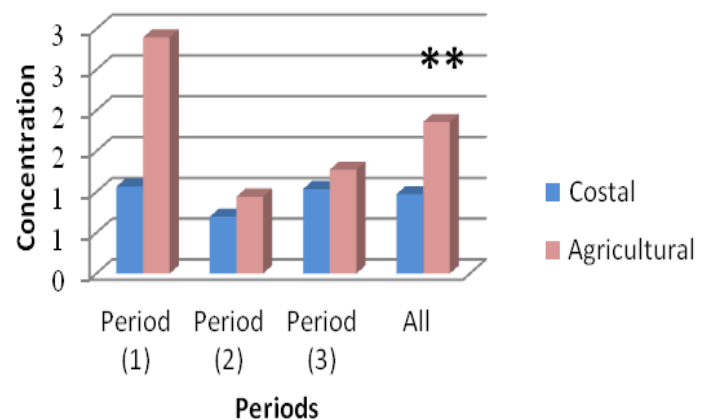

Fig. 7 Diagram showing the concentration of albumin in both costal and agricultural regions at three periods $(* *)$ refers to 0.01 significance level by one- way ANOVA. "All" refers to the difference in the concentration of albumin in the 3 periods collectively between costal and agricultural regions.

\section{Calcium}

Except for period 1, serum calcium was higher a little in Costal region when compared to agricultural region, but there was no significant difference within the same period as tested by one-way ANOVA (Fig. 8). The results showed that there is no significant difference as tested by two-way ANOVA between the concentrations of serum calcium in both costal and agricultural regions regardless of the period.

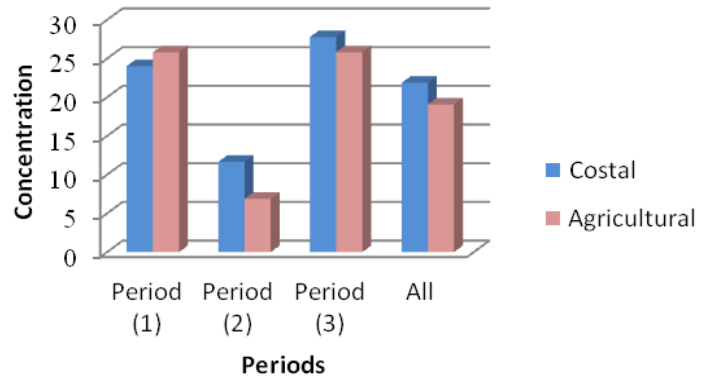

Fig. 8 Diagram showing the concentration of calcium in both costal and agricultural regions at three periods. There is no significant difference as tested by one-way ANOVA. "All" refers to the difference in the concentration of calcium in the 3 periods collectively between costal and agricultural regions. 
Serum sodium in both costal and agricultural regions did not show a significant difference within the three periods as tested by one-way ANOVA (Fig. 9) .While the concentrations of serum sodium was significantly higher $(\mathrm{p}=0.05)$ in period 2 as tested by two-way ANOVA (Fig. 10).

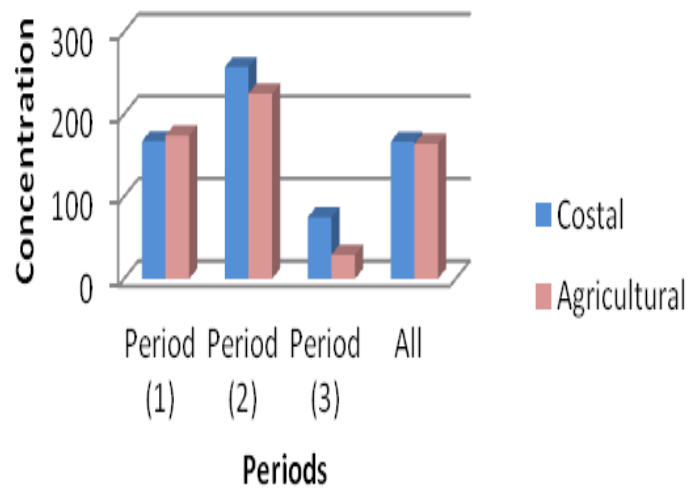

Fig. 9 Diagram showing the concentration of sodium in both costal and agricultural regions at three periods. There is no significant difference as tested by one-way ANOVA. "All" refers to the difference in the concentration of sodium in the 3 periods collectively between costal and agricultural regions.

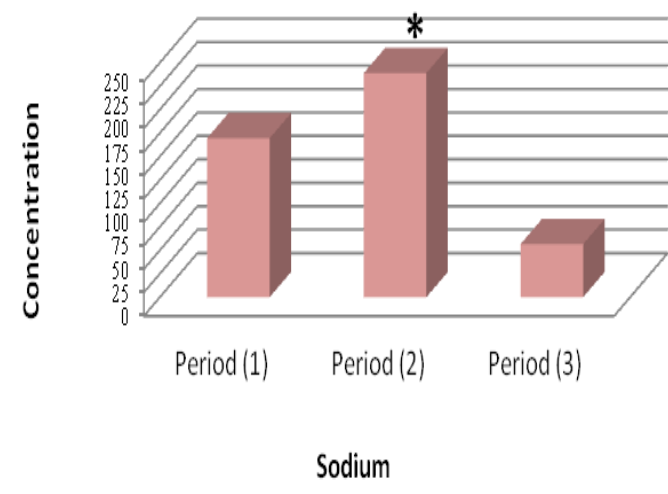

Fig. 10 Diagram showing the concentration of sodium at the three periods. $(*)$ refers to 0.05 significance level as tested by two-way Anova.

\section{Correlation between parasite prevalence and physiological parameters}

The present results showed the presence of a relation between the prevalence of the parasite and the level of some biochemical parameters (Table 2). At high parasite prevalence, an increase in the serum concentration of HDLcholesterol and albumin was observed in the lizards inhabiting agricultural region.

Table 2. Correlation between parasite prevalence and physiological parameters

\begin{tabular}{|c|c|c|c|c|c|c|c|c|}
\hline \multirow[t]{2}{*}{ Locality } & \multirow[t]{2}{*}{ Costal } & \multirow[t]{2}{*}{ Agricultural } & \multicolumn{3}{|c|}{ Costal } & \multicolumn{3}{|c|}{ Agricultural } \\
\hline & & & $\overline{\text { Period 1* }}$ & Period 2 & Period 3 & Period 1 & Period 2 & Period 3 \\
\hline No. of lizards & 19 & 25 & 12 & 2 & 5 & 8 & 7 & 10 \\
\hline Prevalence & $65.50 \%$ & $71.40 \%$ & $70.60 \%$ & $33.30 \%$ & $83.30 \%$ & $61.50 \%$ & $58.30 \%$ & $90.90 \%$ \\
\hline Triglycerides & 280 & 277.2 & 288.9 & 123.3 & 422.3 & 203.4 & 135.1 & 544 \\
\hline Cholesterol & 265.5 & 154.5 & 298.2 & 264.3 & 180.1 & 138.3 & 162.7 & 177.5 \\
\hline HDL-cholesterol & 23.6 & 36.6 & 24.4 & 19.1 & 26.9 & 26.8 & 36.9 & 41.2 \\
\hline LDL-cholesterol & 216.9 & 242.2 & 180.9 & 398.3 & 83.6 & 104.9 & 360.8 & 162.6 \\
\hline Albumin & 0.9 & 1.9 & 1.1 & 0.7 & 1 & 2.9 & 0.9 & 1.3 \\
\hline Calcium & 21.9 & 19.1 & 24 & 11.7 & 27.8 & 25.8 & 6.9 & 25.8 \\
\hline Sodium & 166.5 & 163.4 & 167.1 & 257.3 & 74.6 & 174.2 & 224.9 & 32.7 \\
\hline Total protein & 6.4 & 7.7 & 6.9 & 3.4 & 8.3 & 7.3 & 3.9 & 13.3 \\
\hline Glucose & 76.7 & 60 & 81.5 & 78.6 & 64.6 & 53.8 & 30.9 & 67.8 \\
\hline
\end{tabular}

* Period 1, May-July 2010; Period 2, January-Febrauary2011; period 3, May-July 2011

\section{Sodium}

This indicates a positive correlation between parasite prevalence and these biochemical parameters. On the other hand the concentration of cholesterol, LDL-cholesterol and glucose showed a decrease with the increase in parasite prevalence which indicates negative correlation. For, triglycerides, calcium, sodium and total protein they, didn't show considerable correlation with the parasite prevalence.

\section{Discussion}

Relatively little information is available on the characteristics of helminth communities in reptiles [4-6]. This work aimed to study the 
parasite infracommunity structure of the lizard $C$. ocellatus found at Damietta region and the possible effects of the season as an extrinsic factor in structuring the infracommunity of parasites and the influence of parasite prevalence on the biochemical parameters of the host.

This study found that the nematode $P$. bulbous was the single parasite infecting $C$. ocellatus. Concerning seasonal variation, our results showed that the prevalence of the nematode $P$. bulbous in both costal and agricultural regions was high during period 3 (Summer). Also the results showed that no clear relation was present between the prevalence of the parasite and the variation of some biochemical parameters. This could be due to the small sample size studied in the present investigation.

The seasonal differences in the prevalence of parasite in lizard suggest that infections occur early in the breeding season (Summer), when lizards are more active. It is expected that active lizard eats more foods and consequently exposed to more infective stage of the parasitic nematode, $P$. bulbous. The consistency in the prevalence of infection may reflect the stability of the parasitehost interactions in this population. Our results are similar to those found in the skink T. rugosa by Smallridge and Bull [7].

The concentration of serum triglycerides, cholesterol, calcium, sodium and glucose elevated in the lizards those collected from costal region, while serum HDL-cholesterol, total protein and albumin concentrations are higher in the lizards collected from agricultural region. Reptiles are ectothermic animals and depend on the environment to maintain their physiological, biochemical and immunological processes [810].The interpretation of biochemical results depends on several factors like seasonal variation that must be considered. Only a few normal reference values have been reported in the literature [11,12].

Total lipid levels of between 300 and $1670 \mathrm{mg}$ were reported for reptilian blood [13-16]. The absolute levels of cholesterol encountered in some species of lizards far exceed those recorded for normal man and other species of mammals $[17,18]$. Thus comparative investigations of cholesterol metabolism in these animals are of potential interest because of the widely accepted association between the risk of atherosclerosis and elevated plasma cholesterol in man. The relative proportion of cholesterol esterified in plasma from lizards was remarkably constant considering the large variations in absolute concentrations [19].

Plasma of reptiles of all major groups, however, contains a protein with properties analogous to human albumin: a low molecular weight, hydrophilic protein of relatively high charge. One fraction of their plasma proteins falls in the molecular weight range of albumins, 50,000 to 100,000 [20-23]. The contribution of the albumin to plasma volume appears to vary greatly among different reptiles. The current study confirmed that that the level of serum albumin of $C$. ocellatus was significantly higher in agricultural region when compared to its concentration in Costal region, over the three periods.

High concentrations of albumins with high charge densities are found in active species with high metabolic rates and in those living in dry, hot environments, e.g. those lizards which generally have the highest metabolic rates among reptiles [24-26] and high preferred body temperatures [27]. The normal plasma total protein concentration of lower vertebrates is generally lower than that of mammals. Normal reptiles generally range between 3 and $7 \mathrm{gm} \mathrm{dl}^{-1}$, whereas normal birds generally range between 2.5 and $4.5 \mathrm{~g} \mathrm{dl}^{-1}$. In the recent study serum total protein exceed $7 \mathrm{gm} \mathrm{dl}^{-1}$. Serum total protein of lizards was higher a little in the agricultural region at the three periods.

The blood glucose concentration of normal reptiles and perhaps other ectotherms varies with species, nutritional status, and environmental conditions. The data of Coulson and Hernandez [28] on Alligator mississippiensis and that of Zain-ul-Abedin and Qazi [29] on a variety of turtles, snakes, and lizards showed a consistently higher glucose level than in other reptiles. Values exceeding $150 \mathrm{mg} \mathrm{dl}^{-1}$ are commonly observed. Normal blood glucose concentration of most reptiles ranges between 60 and $100 \mathrm{mg} \mathrm{dl}^{-1}$, but is subject to marked physiologic variation $[28,29]$. The results presented here, however, showed that the serum glucose concentration in lizards collected from Damietta regions (Costal and agricultural regions) ranges between 30 and 90 $\mathrm{mg} \mathrm{dl}^{-1}$ which seem to be lower than reported above. This difference could be related to the type of food available in Damietta region.

Plasma of each of the several orders of the Reptilia shows certain trends in osmotic pressure, $\mathrm{pH}$, and concentration of sodium, chloride, and bicarbonate ions [30]. Total osmolarity, due primarily to electrolytes in all reptiles, is 
relatively high in snakes, lizards, and sea turtles, but is low in fresh water turtles. Sodium, contributing about 90 per cent of the cations, is high in lizards, the normal serum or plasma sodium concentration of most birds and reptiles ranges between 130 and $160 \mathrm{mEq} \mathrm{l}^{-1}$. The normal plasma concentration of calcium for most reptiles ranges between 8 and $11 \mathrm{mg} \mathrm{dl}^{-1}$ and varies with species and physiologic status of the reptile and most likely other ectotherms. For example, some species of tortoises have low blood calcium concentrations [i.e. less than $8 \mathrm{mg} \mathrm{dl}^{-1}$. Hypocalcemia can occur with dietary calcium and vitamin D3 deficiencies, excessive dietary phosphorus, alkalosis, hypoalbuminemia, or hypoparathyroidism. The variation of seasons may effect on the blood calcium concentration that can be less than 8 or more $11 \mathrm{mg} \mathrm{dl}^{-1}$ [31].

\section{Conclusion}

This study focused identifying parasites infecting the lizard $C$. ocellatus in two different regions (costal and agricultural) in New Damietta and revealed the presence of a single parasite species infecting this lizard. Parasite prevalence was high during summer and could not be correlated with biochemical parameters which might be due to the sample size. The increase in parasite prevalence in summer could be related to the high activity of lizards during this period.

\section{References}

[1] R. Polulin, Evolutionary ecology of parasites from individuals to communities. Champman \& Hall, London (1998) p 212

[2] G.W. Esch, A.O. Bush, J.M. AHO, Parasite communities: Patterns and Processes. Champman \& Hall, London and New York (1990)

[3] A.A. Al-Shareef, S.A. Saber, Ecological studies of chalcides ocellatus (Forskal, 1775) and Hemidactylus turcicus (Linnaeus, 1758) from Egypt with special reference to helminthic parasites. Journal of Egyptian Society of Parasitology. 25 (1995) 145-56

[4] J.M. Aho, Helminth communities of amphibians and reptiles: comparative approaches to understanding patterns and processes. In: Parasite communities: patterns and processes. Each G.W., Bush A.O \& Aho J.M. (eds), Champman and Hall, London and New York (1990) p 157-190
[5] V.P. Sharpilo, A. Kostadinova, J. M. Behnke, Y.I. Kuzmin, Helminths of the sand lizard Lacerta agilis (Reptilia, Lacertidae) in the Palaearctic: faunal diversity and spatial patterns of variation in the composition and structure of component communities. Parasitology 123 (2001) 389-400

[6] J.E. Martin, V. Roca, Helminth infracommunitis of Gallotia caesaris caesaris and Gallotintia caesaris gomerae (Sauria: Lacertidae) from the Canary Islands (Eastern Atlantic). Journal of Parasitology 90 (2004) 266-270

[7] C.J. Smallridge, C.M. Bull, Prevalence and intensity of the blood parasite Hemolivia mariae in a field population of the skink Tiquila rugosa. Parasitol Res. 86 (2000) 655-660

[8] K.E. Harr, A.R. Jacobson, P.M. Jacobson, L.K. Maxwell, B.A. Maxwell, R. Benett, E.R. Jacobson, Morphologic and cytochemical characteristics of blood cells and hematologic and plasma biochemical reference ranges in green iguanas. Journal of the American Veterinary Medical Association 218 (2001) 915921

[9] G.P. Brown, R. Shine, Influence of weather conditions on activity of tropical snakes. Austral Ecology (2002) 27

[10] L. Luiselli, G.C. Akani, Is thermoregulation really unimportant for tropical reptiles? Comparative study of four sympatric snake species from Africa. Acta Oecologica 23 (2002) $59-68$

[11] M.L. Campbell, A.H. Turner, Serum protein measurements in the lower vertebrates. I. The colloid osmotic pressure, nitrogen content, and refractive index of turtle serum and body fluid. Biol. Bull. Mar. Biol. Lab., Woods Hole. 73 (1937) 504-510

[12] N.L. Anderson, R.F. Wack, R. Hatcher, Hematology and clinical chemistry reference ranges for clinically normal, captive New Guinea snapping turtle (Elseya novaeguineae) and the effects of temperature, sex and sample type. Journal of Zoo and Wildlife Medicine 28 (1997) 394-403

[13] M.C.D. Nera, Querying chemical, physicochemical and morphological changes on the blood of Testudo graeca in the summer and winter sleep duranteil. Boll. 1st. Zool. R. Univ. Roma 3 (1925) 71-85

[14] I.L. Chaikoff, C. Entenman, The lipids of blood, liver, and egg yolk of the turtle. J. Biol. Chem. 166 (1946) 683-689

[15] K.R. Menon, The glucose and fat levels in the blood of five representative vertebrates. J. Anim. Morph. Physiol. (1954) 65-68

[16] Y. Izard, J. Detrait, P. Boquet, Seasonal variation in the composition of the blood of Vipera aspis. Ann Inst. Pasteur, Paris 100 (1961) 539-545 
[17] C.E. Day, C. Alexander, Comparative electrophoretic profiles of serum lipoproteins: In Atherosclerosis. Vol. Ill Springer, Berlin (1974) 491-493

[18] K.T. Stokke, Cholesteryl ester metabolism in liver and blood plasma of various animal species. Atherosclerosis 19 (1974) 393-406

[19] P.T.M. Gillett, L.M.V. Lima M. C. Costa, M.K.A. Sibrian, Plasma lipid concentrations for some Brazilian lizards. Comp. Biochem. Physiol 64B (1979) 273 - 277

[20] T. Svedberg, K. Andersson, Ultracentrifugal examination of serum from the lower classes of vertebrates. Nature (1938) 142-147

[21] R.C. Roberts, U.S. Seal, Sedimentation analysis of vertebrate serum proteins. Comp. Biochem. Physiol.16 (1965) 327-331

[22] E.F. Baril, J.L. Palmer, A.H. Bartel, Electrophoretic analysis of young alligator serum. Science 13 (1961) 278-279

[23] R.J. Masat, H.C. Dessauer, Plasma albumins of reptiles. Comp. Biochem. Physiol. 25 (1968) 119-128

[24] F.G. Benedict, The physiology of large reptiles. Carnegie Institution of Washington Publications, No. 425 Washington, D.C. (1932)
[25] H.C. Dessauer, Hibernation of the lizard, Anolis carolinensis. Proc. Soc. Exp. Biol. Med. 82 (1953) 351-353

[27] W.R. Dawson, Physiological responses to temperature in the lizard Eumeces obsoletus. Physiol. Zool. 33 (1960) 87-103

[27] W.R. Dawson, T.L. Poulson, Oxygen capacity of lizard bloods. Am. Midi Nat. 68 (1962) 154164

[28] R.A. Coulson, T. Hernandez, Biochemistry of the Alligator. A Study of Metabolism in Slow Motion. Louisiana State University Press, Baton Rouge, Louisiana (1964)

[29] M. Zain-ul-Abedin, M.H. Qazi, Blood sugar levels of some reptiles found in Pakistan. Can. J. Biochem. Physiol. 43 (1965) 831-833

[30] D.S. Dittmer, Blood and other Body Fluids. Biological Handbooks. Federation of American Society for Experimental Biology, Washington, D.C. (1961)

[31] T.W. Campbell, Blood biochemistry of lower vertebrates. American College of Veterinary Pathologists \& American Society for Veterinary Clinical Pathology, Middleton WI, USA (2004)

دراسة طفيلية وبيوكميائية على سحلية الدفان القاطنة لمنطقة دمياط

عبد العزيز عبد الرازق خضر، جمال عبد الرحيم عبد الله، أثرف المتولى سعيد، أحمد مسعد غنيم، ياسمين محمد فؤاد قسم علم الحيوان ـ كلية العلوم- جامعة دمياط جمئ الرئ

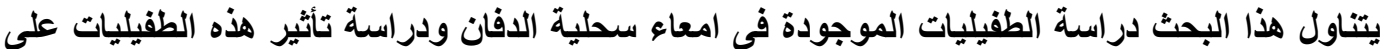

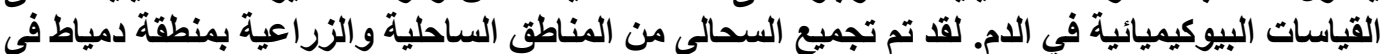

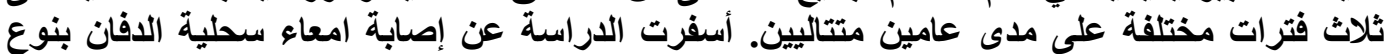

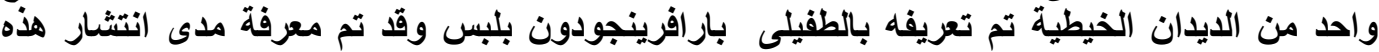

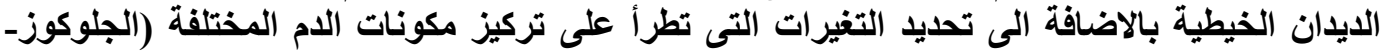

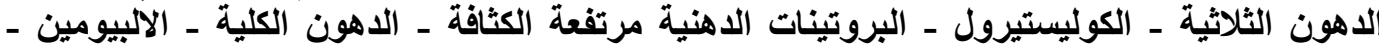

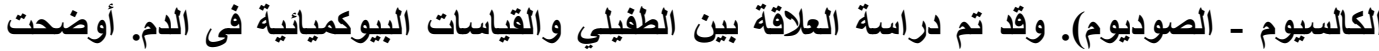

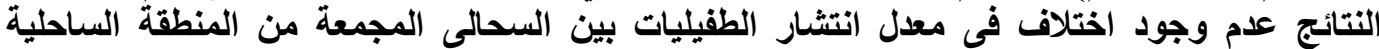

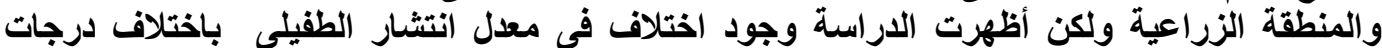

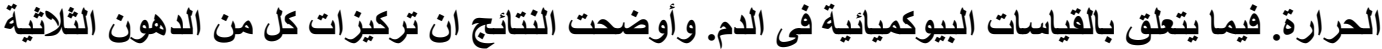

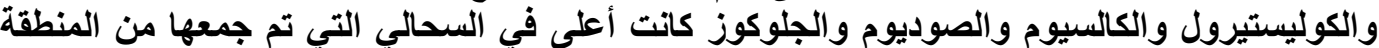

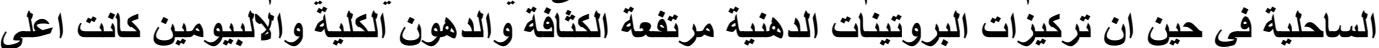

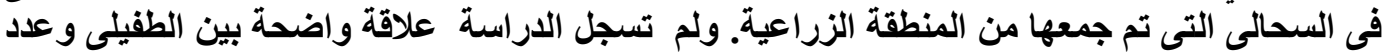

